\title{
PENGARUH LAYANAN BIMBINGAN KELOMPOK DENGAN TEKNIK PERMAINAN UNTUK MENINGKATKAN KONSENTRASI BELAJAR SISWA
}

\author{
Nindya Aryani, Wasidi, Afifatus Sholihah \\ Prodi Bimbingan dan Konseling Fakultas Keguruan dan Ilmu Pendidikan \\ Universitas Bengkulu \\ Nindyaaryani1234@gmail.com, wasidirma@unib.co.id, afifatus@unib.ac.id
}

\begin{abstract}
ABSTRAK
Penelitian ini bertujuan untuk mendeskripsikan pengaruh layanan bimbingan kelompok dengan teknik permainan untuk meningkatkan konsentrasi belajar siswa kelas VIII.3 di SMP Negeri 18 Kota Bengkulu. Penelitian ini merupakan penelitian eksperimen dengan desain penelitian one grup pretest dan postest. Teknik sampling yang digunakan adalah purposive sampling, dimana sampel pada penelitian ini adalah 10 orang siswa kelas VIII.3 di SMP Negeri 18 Kota Bengkulu. Hasil penelitian ini menunjukkan adanya peningkatan yang signifikan pengaruh bimbingan kelompok untuk meningkatkan konsentrasi belajar siswa. Dapat disimpulkan, terdapat pengaruh layanan bimbingan kelompok dengan teknik permainan untuk meningkatkan konsentrasi belajar siswa.
\end{abstract}

Kata kunci : Layanan Bimbingan Kelompok, Teknik Permainan, Konsentrasi Belajar

\section{EFFECT OF GROUP COUNSELING SERVICE WITH GAME TECHNIQUES TO IMPROVE OF THE LEARNING CONCENTRATION}

\begin{abstract}
This study aims to describe the effect of group guidance services with game techniqus to improve learning concentration of the class VIII.3 students of SMP Negeri 18 Kota Bengkulu. This research is an experimental research with one group pretest and postest research design. The sampling technique used was purposive sampling, where the sample in this study were 10 of class VIII.3 SMP Negeri 18 Kota Bengkulu. The results show that study indicate a significant increase in the effect of group guidance to improve learning concentration. It can be concluded, there is an effect of group guidance services with game techniques to the student improve learning concentration.
\end{abstract}

Keywords : Group Guadance Services, Game Techniqus, Learning Concentration 


\section{PENDAHULUAN}

Pendidikan adalah salahh satu unsur penting dallam kebutuhan dasar manusia untuk menjadikan individu mempunyai pemahaman pengetahuan. Pendidikan juga berperan dalam membentuk individu yang berkarakter serta berkualitas yang didapatkan secara formal dan non formal. Salah satu upaya untuk membantu pemerintah untuk mencapai cita-cita bangsa yaitu dengan pendidikan. Pendidikan merupakan cara untuk setiap individu dalam mengembangkan potensinya melalui kegiatan belajar mengajar.

Pembelajaran ialah proses yang dilaksanakan oleh pendidik dan peserta didik dalam pemberian pendidikan dan pelatihan dalam upaya mencapai suatu tujuan. Pembelajarann itu sendiri dapat diterapkan secara tatap muka dan dapat juga dilakukan secara jarak jauh dengan bantuan jaringan atau dapat dikatakan pembelajaran secara online (online learning). Pada proses pembelajaran daring didalamnya mengaitkan teknologi informasi pada saat pembelajaran berlangsung (Fitriyani et al., 2020: 166). Pembelajaraan secara daring merupakan proses belajar mengajar yang mana tidak diterapka secara tatap muka melainkan proses pembelajaran ini berjalan dengan jaringan (Pohan, 2020:2). Menurut Husaini (dalam Fitriyani et al., 2020: 166), dengan adanya teknologi dalam dunia pendidikan dapat dijadikan sebagai sarana dalam penyampaian pembelajaran yang interaktif maupun searah pada siswa. Salah satu upaya untuk mencapai proses pembelajaran berhasil dan dapat mencapai tujuan yaitu jika siswa berrkonsentrasi ketika berlangsungnya proses pembelajaran.

Konsentrasi siswa adalah hal yang penting pada proses pembelajaran. Seperti yang dikemukakan oleh Surya (dalam Malawi \& Tristiar, 2016:119) kurangnya kemampuan siswa dalam konsentrasi menyebabkan turunnya prestasi belajar siswa. Ini berarti konsentrasi belajar sangat penting sebagai pondasi dalam peningkatan prestasi belajar siswa. Konsentrasi yang optimal dari siswa pada saat proses pembelajaran berlangsung ini dapat membantu siswa untuk mencapai peningkatan prestasi belajar. Selanjutnya Slameto (dalam Jusriana, 2019: 139) menjelaskan bahwa konsentrasi belajar merupakan pengaruh yang besar terhadap belajar. Siswa yang konsentrasi belajarnya rendah semua waktu belajarnya akan terbuang percuma, baik itu dalam segi waktu, tenaga dan biaya. Apabila konsentrasi siswa rendah, maka aktivitas yang ditimbulkan oleh siswa itu rendah juga dan dapat menimbulkan ketidak seriusan siswa ketika belajar (Malawi \& Tristiar, 2016:119). Berbeda dengan siswa yang tingkat konsentrasi belajarnya tinggi, ia akan menyerap setiap proses pembelajaran sehingga ia dapat belajar dengan baik. Masalah mengenai kesulitan konsentrasi merupakan salah satu ciri adanya 
masalah dalam belajar yang dihadapi oleh siswa untuk mencapai keberhasilan dalam belajar. Pada Bimbingan dan Konselingg terdapat layanan yang bisa digunakan untuk membantu klien dalam pengembangan dirinya, termasuk kesulitan dalam konsentrasi belajar. Mengatasi hal tersebut peneliti memanfaatkan salahh satu layanan yang ada yaitu layanan bimbingan kelompokk.

Prayitno (dalam Alamri, 2015) berpendapat bahwa layanan bimbingan kelompok ialah suatu prosess dalam memberikan informasi pengetahuan serta bantuan dengan memanfaatkan dinamika kelompok pada sekelompok orang untuk mencapai suatu tujuan. Lebih lanjut Sukardi (dalam Aliyah, 2019:12) berpendapat bahwa bimbingan kelompok adalah layanan bimbingan yang dapat diperoleh siswa dalam pemberian bahan informasi dari narasumberr (terutama guru $\mathrm{BK} /$ konselor) yang dapat digunakan untuk pengambilan keputusan keseharian siswa sebagai peserta didik, anggota keluargaa ataupun sebagai anggota masyarakat. Bimbingan kelompokk juga merupakan faktor yang berpengaruh dalam peningkatan konsentrasi belajar siswa. Menurut Prayitno (dalam Putu et al., 2014), mengatakan bahwa secara umum untuk membantu siswa yang mengalami permasalahan dapat diberikan layanann bimbingan kelompokk. Ini berarti layanan ini dapat juga digunakan untuk mengatasi siswa yang mengalami kesulitan konsentrasi dengan menggunakan kelompok. Menerapkan teknik dalam bimbingann kelompok juga dapat membantu dalam upaya mencapai tujuan dari kegiatan yang telah ditetapkan.

Romlah (dalam Alamri, 2015) berpendapat bahwa, teknik yang digunakan dalam layanan bukan sebuah tujuan namun teknik digunakan guna pencapaian suatu tujuan kegiatan. Dalam upaya pencapaian tujuan pada Bimbingan kelompok ini dapatdengan menerapkqn teknik dan salah satu teknik yang dapat digunqkan dalam pelaksanaan Bimbingan kelompok ialah tekniik permainan. Menggunakan teknik pada layanan selain untuk mencapai tujuan juga di gunakan agar anggota kelompok tidak bosan serta kegiatan dalam Bimbingan kelompok tidak monoton. Teknik permainan merupakan suatu metode yang bisa dipakai untuk membantu dalam proses pembelajaran agar dapat mengasah perasaan, pikirann, kemampuan serta perhatian agar prosesbelajar mengajar dapat memperoleh tujuan yang diharapkan (Ramadhani et al., 2020: 85). Pada teknik permainan ini pelaksanaannya membuat suasana lebih relax dan gembira, sehingga pada suasana ini seseorang dapat lebih baik dan bersungguh-sungguh dalam proses belajarnya.

Berdasarkan pada uraian latar belakang, maka perlu diteliti mengenai "Pengaruh Layanan Bimbingan Kelompok dengan Teknik Permainan untuk Meningkatkan Konsentrasi Belajar Siswa Kelas VIII.3 di SMPN 18 Kota Bengkulu”. 


\section{METODE PENELITIAN}

Desain pada penelitian ini menggunakan desain penelitian kuantitatif dengan metode eksperimen. Menurut Sugiyono (2019: 15), metode penelitian kuantitatiif merupakan sebuah metode penelitian yang berasaskan pada fiilsafat positivisme, metode penelitian ini dapat dipakai untuk meneliti suatu sampel terpilih atau populasi dengan pengambilan sampel acak, penghimpunan data digunakan untuk instrumen penelitiann, analisis data yang berupa kuantitif/statistik serta bermaksud untuk membuktikan hipotesis yang ada. Penelitian ini menggunakan desain one-group pretest-posttest design.

Populasi yang ada pada penelitian ini yaitu siswa kelas VIII SMPN 18 Kota Bengkulu dengan jumlah 30 orang. Sampel pada penelitian ini adalah 10 siswa yang berada pada tingkat konsentrasi belajar yang rendah. Teknik purposive sampling digunakan dalam upaya pengambilan sampel pada penelitianb ini.

Teknik pengumpulanb dataa yang digunakan pada penelitian ini yaitu angket atau kuesioner. Angket atau kuesioner adalah suatu cara untuk mengumpulkan data dengan cara diberikannya pertanyaan atauu pernyataann secara tertulis kepada responden untuk dijawab (Sugiyono, 2019: 219). Penggunaan angket skala likert digunakan pada penelitisn ini. Menurut Azwar (2012: 80) daya bedaq yaitu sejauh mana item mampu membedakan antara individu atau kelompok individu yang memiliki dan tidak memiliki atribut yang diukur. Uji daya beda angket konsentrasi belajar yang diberikasn item yang tidak memenuhi kriteria uji daya beda yaitu $<0.30$. Terdapat 9 item yang gugur pada uji daya beda yaitu item dengan nomor $2,4,18$, 29, 35, 40, 41, 46 dan 50.

Menurut Arikunto (dalam Payadnya \& Jayantika, 2018: 31) reliabilitas yaitu merujuk pada pengertian bahwasanya instrument sudah memenuhi sebagai alat pengumpulan data dikarenakan instrumen itu telah dikategorikan baik. Suatu kuesioner dapat dikatakan baik apabila nilai Alpha dari skala > 0.70. Setelah melakukan uji reliabilitas dengan bantuan aplikasi Statistical Product and Service Solutions (SPSS) dengan versi 16.0 diperoleh skor Cronbach's Alpha sebersar 0.961 yang berarti > 0.70 sehingga dapat dikatakan instrumen angket yang digunakan memiliki reliabilitas yang baik.

\section{HASIL DAN PEMBAHASAN}

Pelaksanaan penelitian ini yaitu di semester genap tahun ajaran 2021 tepatnya pada 9 Agustus sampai dengan 29 September 2021 di SMP Negeri 18 Kota Bengkulu. Populasi di 
penelitianb ini adalah siswa kelas 8.3 yang berjumlah 32 orang dengan sampel penelitian 10 orang. Peneliti memberikan angket pre-test guna mencari siswa yang memiliki konsentrasi belajar pada taraf rendah, kemudian diberikanb treatment bimbingan kelompok dengan teknik permainan agar konsentrasi belajar siswa meningkat. Kemudian setelah diberikan treatment sampel diberikan lagi angket post-test guna melihat terdapat kenaikan tingkat konsentrasi belajar siswa setelah diberikan layananb.

Kategori skor pada konsentrasi belajar siswa dapat dikategorikan dengan skor sangat rendah, rendahb, tinggii dan sangat tinggi. Penetapan skor distribusi bergolong yaitu sebagai berikut :

Tabel 1

Distribusi Skor Penilaian Konsentrasi Belajar

\begin{tabular}{cc}
\hline Skor & Kategori \\
\hline $136.5-202.5$ & Sangat Tinggi \\
\hline $102.5-136$ & Tinggi \\
\hline $68-101.75$ & Rendah \\
\hline $33.75-67.5$ & Sangat Rendah
\end{tabular}

Berdasarkan penentuan kategori pada Tabel 1 dan pemberian angket pre-test yang diberikan pada peserta didik menghasilkan:

Tabel 2

Distribusi Frekuensi Pre-test Siswa yang Memiliki Tingkat Konsentrasi Belajar Rendah

\begin{tabular}{cccc}
\hline Kategori & Rentang & Skor & Presentase (\%) \\
\hline Sangat Rendah & $33,75-67,5$ & - & - \\
\hline Rendah & $68-101,75$ & 10 & $100 \%$ \\
\hline Tinggi & $102,25-136$ & - & - \\
\hline Sangat Tinggi & $136,5-202,5$ & - & - \\
\hline \multicolumn{2}{c}{ Total } & 10 & $100 \%$ \\
\hline
\end{tabular}

Menurut Tabel 2 terlihat 10 orang siswa memiliki tingkat konsentrasi belajar yang rendah dengan persentase $100 \%$. Hasil yang didapatkan dari angket pre-test bahwa tidak terdapat siswayang berada pada tingkat konsentrasi belajar yang tinggi atau sangat tinggi.

Setelah pemberian angket pre-test kemudian diberikan treatment bimbinganb 
kelompokk dengan teknik permainan dan dilanjutkan dengan pemberian angket post-test. Berdasarkan angket post-test yang diberikan diperoleh skor hasil sebagai berikut :

Tabel 3

Distribusi Frekuensi Post-Test Tingkat Konsentrasi Belajar

\begin{tabular}{cccc}
\hline Kategori & Rentang & Skor & Presentase (\%) \\
\hline \multirow{2}{*}{ Sangat Rendah } & $33,75-67,5$ & - & - \\
\hline Rendah & $68-101,75$ & - & - \\
\hline Tinggi & $102,25-136$ & 9 & $90 \%$ \\
\hline Sangat Tinggi & $136,5-202,5$ & 1 & $10 \%$ \\
\hline \multicolumn{2}{c}{ Total } & 10 & $100 \%$ \\
\hline
\end{tabular}

Berdasarkan Tabel 3 hasil angket post-test yang telah diberikan terdapat 1 siswa dengan persentase $10 \%$ dengan kategori sangat tinggi. Kemudian terdapat 9 siswa dengan persentase 90\% dikategorikan tinggi. Hasil dari analisis angket post-test ini terdapat 2 kategori hasil yaitu tinggi dan sangat tinggi. Berdasarkan hasil angket post-test tidqk terdapat lagi siswa yang termasuk pada kaategori rendah, sehingga dapat disimpulkan bahwa hasil post-test kepada 10 orang siswa kelas VIII.3 mengalami peningkatan setelah diberikan treatment.

Tabel 4

Perbandingan skor Pre-Test dan Post-Test Konsentrasi Belajar Siswa

\begin{tabular}{cccclc}
\hline $\begin{array}{c}\text { Kode } \\
\text { siswa }\end{array}$ & Skor & Kategori & Skor & Kategori & Kenaikan \\
\hline CJS & 81 & Rendah & 103 & Tinggi & 22 \\
\hline FDF & 78 & Rendah & 104 & Tinggi & 26 \\
\hline DMR & 80 & Rendah & 107 & Tinggi & 27 \\
\hline STS & 82 & Rendah & 105 & Tinggi & 23 \\
\hline MDD & 84 & Rendah & 122 & Tinggi & 38 \\
\hline MDA & 85 & Rendah & 105 & Tinggi & 20 \\
\hline MIP & 88 & Rendah & 137 & $\begin{array}{l}\text { Sangat } \\
\text { Tinggi }\end{array}$ & 49 \\
\hline RCP & 77 & Rendah & 111 & Tinggi & 34 \\
\hline DF & 78 & Rendah & 104 & Tinggi & 26 \\
\hline PAF & 76 & Rendah & 103 & Tinggi & 27 \\
\hline Jumlah & 809 & & 1101 & & \\
\hline Tertinggi & 88 & & 137 & & \\
\hline Terendah & 76 & & 103 & & \\
\hline & & & & & \\
\hline
\end{tabular}




\begin{tabular}{lllll}
\hline Mean & 80,90 & Rendah & 110,10 & Tinggi \\
\hline
\end{tabular}

Berdasarkan Tabel 4 dapat disimpulkan bahwa peningkatan konsentrasi belajar yang diperoleh 10 orang siswa sebelum dan sesudah diberikan treatment, sebelum diberikan treatment rata-rata skor siswa yaitu 80,90 yang mana dikategorikab renddah. Setelah pemberian layanan pada siswa terjadi peningkatan skor yaitu menjadi 110 yang termasuk dalam kategori tinggi. Terlihat Tabel 4 diatas terdapat siswa dengan peningkatan skor nilai yang tinggi yaitu 49, hal ini karena ketika kegiatan bimbingan kelompok klien aktif serta memahami apa yang diberikan dalam kegiatan.

Penggunaan analisis data pada penelitian ini yaitu dengan statistic compare means dengan menggunakan rumus Paired Sample T-test. Pengambilan keputusan hipotesis diterima atau ditolak yaitu dengan cara apabila nilai Sig (2-tailed) $<0,05$ maka Ho ditolak, namun apabil nilai Sig (2-tailed) >0,05 maka Ho diterima.

Tabel 5

Paired Samples T-test

\begin{tabular}{ccc}
\hline & $T$ & Sig. (2-tailed) \\
\hline Pretest-Posttest & -10.488 & .000 \\
\hline
\end{tabular}

Dilihat dari Tabel 5 hasil $\mathrm{P}=0.000, \mathrm{p}<0.05$ sehingga Ho ditolak dan Ha diterima. Berdasarkan hal tersebut dapat disimpulkan bahwa terdapat pengaruh layanan bimbingan kelompok dengan teknik permainan untuk meningkatkan konsentrasi belajar siswa kelas VIII.3 SMPN 18 Kota Bengkulu.

Konsentrasi adalah hal penting pada proses pembelajaraqn. Konsentrasi belajar bukan merupakan bakat terpendam seseorang yang ada sejak ia lahir, tetapi konsentrasi belajar diwujudkan dan direncaqnakan serta dijadikan kebiasaan dalam belajar. Konsentrasi belajar ialah memfokuskan daya pikiran serta aktivitas pada suatu tujuan yang sedang dipelajari dengan menyingkirkan hal-hal yang tidak berkaitan dengan tujuan yang sedang dipelajari (Surya, 2009: 22).

Menurut Daud (dalam Isnawati, 2020: 80) konsentrasi belajar adalah pemusatan perhatian yang dilakukan oleh individu dalam proses perubahan tingkah laku dan hasilnya yaitu dalam penguasaan. Hal serupa juga disampaikan Dimyati dan Mudjiono (dalam Safitri, 2020), konsentrasi belajar merupakan suatu kemampuan individu untuk memfokuskan perhatiannya pada pelajaran yang berkenaan dengan isi bahan belajar maupun proses dalam memperolehnya. Siswa yang konsentrasi belajarnya rendah semua waktu belajarnya akan terbuang percuma, baik itu dalam segi waktu, tenaga dan biaya. Apabila konsentrasi siswa 
rendah, maka aktivitas yang ditimbulkan oleh siswa itu rendah juga dan dapat menimbulkan ketidak seriusan siswa ketika belajar (Malawi \& Tristiar, 2016:119). Berbeda dengan siswa yang tingkat konsentrasi belajarnya tinggi, ia akan menyerap setiap proses pembelajaran sehingga ia dapat belajar dengan baik. Pemberian layanan bimbingan kelompok dapat diterapkan untuk langkah pemahaman siswa mengenai konsentrasi belajar sehingga terdapat peningkatan konsentrasi belajar siswa.

Menurut Nurihsan (dalam Ramadhaniar, 2018: 24) bimbingan kelompok adalah kegiatan untuk menginformasikan sesuatu pada kelompok siswa yang ada di sekolah yang pembahasannya permasalahan tentang pendidikan, pekerjaan, pribadi dan sosial individu. Bimbingan kelompok dirasa lebih efektif sebab dapat terjadi pertukaran pengalaman, pemikiran, perencanaan dan menyelesaikan suatu permasalahan antar anggota kelompok. Pemberian layanan bimbingan kelompok ini bertujuan untuk peningkatan siswa mengenai konsentrasi belajarnya melalui pemahaman informasi yang telah diberikan.

Pemberian layanan bimbingan kelompok ini juga disertai dengan teknik yang diterapkan dalam layanan. Teknik yang diterapkan adalah teknik permainan, dengan penerapan teknik permainan ini upaya untuk mencapai tujuan layanan dapat tercapai. Menurut Agus (dalam Adhityaputra \& Saripah, 2015: 293) teknik permainan adalah teknik yang digunakan guna menjadikan suasana belajar yang santai dan nyaman sehingga dapat membantu siswa dalam menyelesaikan permasalahan, perencanaan, pengambilan keputusan dan memperkuat kepribadian. Teknik permainan ini dirasa efektif digunakan untuk penyampaian informasi karena permainan merupakan hal yang menyenangkan dan lebih mudah diterima oleh anggota kelompok.

Keterlaksanaan layanan ini dilaksanakan pada siswa dengan 6 kali pertemuan dengan bertatap muka di dalam ruang kelas dan virtual melalui zoom meeting. Setelah diberikan angket pre-test terpilihlah 10 anak yang memiliki tingkat konsentrasi belajar yang rendah. Hal ini terlihat dari jumlah skor angket yaitu 809 dan nilai rata-rata angket dari keseluruan anak yaitu 80,90 yang termasuk dalam kategori rendah. Pemberian angket pre-test ini dengan tujuan mengetahui taraf konsentrasi belajar peserta didik kemudian diketahui tingkat konsentrasi belajar peserta didik rendah sebelum diberikan treatment.

Terjadilah peningkatan tingkat konsentrasi belajar siswa setelah diberikan treatment berupa layanan bimbingan kelompok, yang mana ini terlihat dari data angket post-test. Menurut data angket post test yang telah diberikan pada sekelompok siswa terjadi peningkatan karena skor yang didapat siswa tidak ada lagi yang dikategorikan rendah. Ini terlihat dari peningkatan skor jumlah yang signifikan dari 809 menjadi 1101 dan nilai rata-rata dari 80,90 menjadi 
$110,10$.

Hasil angket post-test siswa yang mendapatkan skor Sangat tinggi yaitu MIP dari 88 menjadi 137 dan selebihnya siswa mendapatkan skor tinggi yaitu CJS dari 81 menjadi 103, FDF dari 78 menjadi 104, DMR dari 80 menjadi 107, STS dari 82 menjadi 105, MDD dari 84 menjadi 122, MDA dari 85 menjadi 105, RCP dari 77 menjadi 111, DF dari 78 menjadi 104 dan PAF dari 76 menjadi 103. Berdasarkan hal tersebut bisa ditarik kesimpulan bahwa terdapat kenaikan tingkat konsentrasi belajar siswa setelah diberi treatment.

Pemberian layanan bimbingan kelompok dengan teknik permainan dengan pemimpin kelompok memberikan topik tugas kepada para anggota yang selanjutnya terdapat pembahasan secara berkelompok disertai pemanfaatan dinamika kelompok. Peningkatan ini dapat dilihat dari anggota kelompok yang awalnya masih belum berani untuk aktif dalam kegiatan dapat berani menyampaikan pendapat setelah beberapa kali mengikuti kegiatan bimbingan kelompok. Hal tersebut juga didukung oleh penggunaan teknik permainan yang diterapkan dalam setiap kegiatan sehingga siswa menjadi lebih bersemangat ketika mengikuti kegiatan. Pada penerapan teknik permainan ini setiap siswa terlibat secara langsung dengan permainan yang telah ditentukan oleh peneliti baik secara langsung maupun secara virtual. Permainan yang digunakan dalam kegiatan bimbingan kelompok ini diantaranya yaitu tes lima menit, tebak kata, tepuk nyamuk, tebak huruf akhir, lanjutkan ceritaku dan tebak warna. Pada setiap pelaksanaan teknik permainan ini setiap anggota sangat antusias untuk mengikutinya.

Hasil penelitian yang sudah dilakukan peneliti terdahulu ada kesamaan hasil denggan penelitian iini yakni layanan bimbingan kelompok dengan teknik permainan terdapat pengaruh dalam peningkatan konsentrasi belqjar siswa. Dapat disimpulkan bahwa pemberian layanan bimbingan kelompok dengan teknik permainan yang sesuai prosedur cukup efektif untuk meningkatkan konsentrasi belajar siswa.

\section{KESIMPULAN}

Penelitian yang telah dilaksanakan, dapat diambil kesimpulan bahwa konsentrasi belajar siswa kelas VIII.3 SMPN 18 Kota Bengkulu sebelum diberikqn layanan bimbingan kelompokk dengqn tekniik permainan tergolong rendah, ini dapat dilihat berdasarkan analisis skor angket pre-test yang diberi pada siswa. Skor rata-rataq angket konsentrasi belajar yang diperoleh siswa yaitu 80,90 yang mana ini termasuk dalam kategori rendah. Serta konsentrasi belajar siswq kellas VIII.3 SMPN 18 Kota Bengkulu setela diberi treatment bimbingan kelompok dengan teknik permainan terdapat kenaikan skor dari peserta didik. Ini terlihat berdasarkan pada analisis angket post-test yang menyatakan skor tinggi dan sangat tinggi. Rata- 
rata skor Angket konsentrasi belajar siswa yaitu 110,10 sehingga termasuk kategori tinggii. Berkaitan dengan hasil uji hipottesis yang, maka Ha diterimq dan Ho ditolakk, sehingga disimpulkan bahwa layanan bimbingan kelompok dengan teknik permainan berpengaruh terhadap peningkatan konsentrasi belajar siswa kelas VIII.3 SMPN 18 Kota Bengkulu.

Saran yang diberi oleh peneliti untuk guru BK, hasil penelitian ini digunakan untuk menambah ilmu dan pengetahuan sehingga bisa digunakan sebagai pertimbangan dalam pemberian layanan bimbingan konseling. Terutama dalam memberikan layanan bimbingan kelompok dengan teknik permainan yang mempunyai taraf konsentrasi belajar yang rendah, Bagi siswa, melalui kegiatan bimbingan kelompok yang telah dilakukan ini agar mampu menerapkan informasi dari topik yang telah dibahas sehingga dapat berkonsentrasi dengan baik selama proses pembelajaran, Bagi peneliti selanjutnya, hasil penelitian ini dapat dijadikan bahan acuan untuk mengembangkan dan menyempurnakan penelitian selanjutnya, Bagi sekolah,, diharapkan dapat memfasilitasi siswa dan guru BK dalam upaya pemberiqn layanan bimbingan dan konseling.

\section{DAFTAR PUSTAKA}

Adhityaputra, V. W., \& Saripah, I. (2015). Efektivitas Teknik Permainan Untuk Meningkatkan Keterampilan Komunikasi Interpersonal Pada Remaja. Edusentris, 2(3), 290. https://doi.org/10.17509/edusentris.v2i3.181. Diunduh pada 23 Juni 2021.

Alamri, N. (2015). Layanan Bimbingan Kelompok Dengan Teknik Self Management Untuk Mengurangi Perilaku Terlambat Masuk Sekolah (Studi Pada Siswa Kelas X SMA 1 Gebog Tahun 2014/2015). Jurnal Konseling Gusjigang, 1(1). https://doi.org/10.24176/jkg.v1i1.259. Diunduh Pada 29 Januari 2021.

Aliyah, Himatul. (2015). Implementasi Layanan Bimbingan Kelompok Dalam Meningkatkan Prestasi Belajar Siswa Kelas XII IPA di SMAN 1 Gedangan Sidoarjo. Skripsi. Diunduh pada 28 Januari 2021.

Azwar, Saifuddin. (2012). Relibilitas dan Validitas. Yogyakarta:Pustaka Pelajar.

Fitriyani, Y., Fauzi, I., \& Sari, M. Z. (2020). Motivasi Belajar Mahasiswa Pada Pembelajaran Daring Selama Pandemik Covid-19. Profesi Pendidikan Dasar, 7(1), 121-132. https://doi.org/10.23917/ppd.v7i1.10973. Diunduh pada 19 Februari 20121.

Isnawati, Ruslia. (2020). Cara Kreatif Dalam Proses Belajar (Konsentrasi Belajar Pada Anak Gejala Gangguan Pemusatan Perhatian (ADD)), Surabaya: CV. Jakad Media Publishing.

Jusriana. (2019). Implementasi Metode Pembelajaran Discovery Dalam Meningkatkan Kedisiplinan Dan Konsentrasi Belajar Peserta Didik Kelas Xi B Ma Madani Alauddin Paopao. Jurnal Pendidikan, 3(2), 137-142. http://journal.uinalauddin.ac.id/index.php/PendidikanFisika/article/viewFile/3734/3408. Diunduh pada 19 Februari 2021.

Malawi, I., \& Tristiar, A. (2016). Pengaruh Konsentrasi Dan Kemampuan Berpikir Kritis Terhadap Prestasi Belajar Ips Siswa Kelas V Sdn Manisrejo I Kabupaten Magetan. Premiere Educandum: Jurnal Pendidikan Dasar Dan Pembelajaran, 3(02), 118-131. https://doi.org/10.25273/pe.v3i02.272. Diunduh pada 26 Januari 2021.

Payadnya \& Jayantika. (2018). Panduan Penelitian Eksperimen Beserta Analisis Statistik 
dengan SPSS. Yogyakarta: CV Budi Utama.

Pohan, A. E. (2020). Konsep Pembelajaran Daring Berbasis Pendekatan Ilmiah. PurwodadiGrobogan: CV Sarnu Untung.

Putu, N., Nonik, S., Sulastri, M., \& Sedanayasa, G. (2014). Mengalami Kesulitan Belajar Siswa Kelas X4 Sma Negeri 1 Sukasada. E-Journal Undiksa Jurusan Bimbingan Konseling, 2(1). Diunduh pada 31 Januari 2021.

Ramadhaniar, Prana. Upaya Meningkatkan Konsentrasi Belajar Siswa Melalui Layanan Bimbingan Kelompok di Kelas VIII-7 MTs N Deli Serdang. Skripsi. Diunduh pada 29 Januari 2021.

Sugiyono. (2019). Metode Penelitian Kuantitatif. Bandung: Alfabeta

Surya, H. (2009). Menjadi Manusia Pembelajar. Jakarta: PT Elex Media Komputindo.

Ramadhani; Yulia R; Masrul; Rahmi R; Rani R; Andi F.T; Juliana S.D; Anita P; Tasnim; Arsen N.P; Muhammad A.AB; Tuti A; Cahyo P; dan Janner S. (2020). Metode dan Teknik Pembelajaran Inovatif. Medan: Yayasan Kita Menulis. 

ISSN 2599-1221 (Cetak) 